Research Article

\title{
Failure Mechanism and Mitigation Measures of the G1002 Electricity Pylon Landslide at the Jinping I Hydropower Station
}

\author{
Gang Luo (D), Yutian Zhong, and Yuanxiang Yang \\ Faculty of Geosciences and Environmental Engineering, Southwest Jiaotong University, Chengdu 610031, China \\ Correspondence should be addressed to Gang Luo; luogang@home.swjtu.edu.cn
}

Received 1 July 2020; Revised 2 August 2020; Accepted 28 August 2020; Published 18 September 2020

Academic Editor: Chunshun Zhang

Copyright (C) 2020 Gang Luo et al. This is an open access article distributed under the Creative Commons Attribution License, which permits unrestricted use, distribution, and reproduction in any medium, provided the original work is properly cited.

\begin{abstract}
On August 29 and 30, 2012, local extreme rainfalls struck the construction area of the Jinping I Hydropower Station, Xichang, China, and triggered many geohazards. The upper region of the left valley slope $200 \mathrm{~m}$ downstream of the dam failed and slid, exposing the D-pile of the G1002 electricity pylon and threatening the entire power transmission line. Therefore, guaranteeing the stability of the residual soil masses in the rear area of the main scarp and the safety of the G1002 electricity pylon became a primary emergency task. Geological field surveys, topographical mapping, study of the failure mechanisms, and stability evaluations were carried out from October 12, 2012, to November 7, 2013. It is revealed that the failure mechanism of the G1002 electricity pylon landslide is flood-induced tractive sliding along the interlayer between the colluvium and the bedrock, significantly influenced by heavy precipitation and frequent blasting activities during the dam construction. The residual soil masses around the G1002 electricity pylon foundation are unstable under rainfall conditions. In order to ensure the stability of the residual soil masses and pylon foundation, a mitigation measure of the anchor cables combined with lattice frame beams was proposed and applied in practice. This paper provides insights into the problems associated with the selection of the locations of electricity pylons in ravine regions as well as mitigation strategies for similar landslides.
\end{abstract}

\section{Introduction}

Landslide hazards due to increasing population density and infrastructure development in canyon areas are inevitable. Risks associated with landslides are increasing due to climate change and increasing engineering construction activities $[1,2]$. Many slope failures during rainstorms are associated with the hydrodynamic pressure on the sliding surface, rising groundwater table, and increasing pore pressure in saturated unconsolidated sediments $[3,4]$. The initiation mechanism of rainfall, soil types, topography, and hydraulic and mechanical parameters of the soil are well documented [5-9]. However, in contrast to flood-induced landslides in tropical areas [10], occurrences of such landslides in alpine valley regions have been rarely reported, and the failure of colluvium eroded by successive floods has rarely been considered compared with the saturation-type failure.

Abundant flume experiments on debris flows showed that the initiation processes include surface runoff, movement of fine particles, falling of large particles, movement of the whole slope, and debris flow formation $[11,12]$. In unconsolidated soil with a wide grading and loose structure, the factors triggering debris flows are floods or large runoff, in addition to strong rainfall $[13,14]$. Although it has been emphasized that $13.9 \%$ of the landslides were caused by erosion [15], the effects of floods and torrential runoff in mountainous areas, which are significant disaster factors for debris flows or landslides, remain unclear. In addition, management agencies for floods and landslides are developing independently; therefore, flood and landslide events have been separately organized and processed $[10,16]$. Previously established initiation models for debris flows, such as coupled hydraulics and soil mechanics models [17], surface runoff model [6], and runoff threshold model [13] mainly refer to the channel bed erosion rather than the lateral erosion. Thus, geological investigations and design stages should focus on the lateral erosion of accumulative deposits by floods and preliminary protection measures for the same. 
On August 29 and 30, 2012, local extreme rainfall hit the construction area of the Jinping I Hydropower Station, inducing more than 100 geological disasters $\left(26.70^{\circ} \mathrm{N} /\right.$ $109.18^{\circ} \mathrm{E}$ ) [18]. This event resulted in 10 fatalities, 14 missing, and more than 13,000 people being trapped in construction camp III. Several bridges and power transmission lines broke down. At the same time, an expected shallow colluvium landslide occurred beside the G1002 electricity pylon. In the rear area of the main scarp, a tractive deformation zone with several cracks and notable subsidence was formed, exposing the D-foundation pile of the G1002 electricity pylon. Due to subsequent retrogressive erosion by precipitations, the tractive deformation zone would destabilize, which threatened the safety of the G1002 electricity pylon and the entire transmission line (Figure 1). Instead of focusing on the mitigation of the G1002 electricity pylon landslide (EPL) itself, the protection of the G1002 electricity pylon was considered to be more important for the main stakeholder-China Power Engineering Consulting (Group) Corporation. Authorized by the stakeholder, geological field surveys, topographical mapping, study of the failure mechanisms, stability evaluation, and emergency mitigation were conducted from October 2012 to November 2013.

This paper describes the geomorphic characteristics of the G1002 EPL and discusses the failure mechanism of shallow colluvium landslides in sinuous steep-sided gorges. Considering the object to be protected, cost, and implementation, anchor cables combined with lattice frame beams and crack sealing were proposed as mitigation measures, which provide reference for similar events.

\section{Geological and Environmental Setting of the Research Area}

2.1. Location and Traffic. The Jinping I Hydropower Station is located at a sharp bend in the middle reaches of Yalong River, where the transition area is present between the Qinghai-Tibet Plateau and the Sichuan Basin (Figure 1). The hydropower dam height is $305 \mathrm{~m}$ (up to $1885 \mathrm{~m}$ a.s.l.), the retained reservoir level is $1880 \mathrm{~m}$ a.s.l., and the natural level of the river is $1630 \mathrm{~m}$ a.s.l. [19]. The only access to the G1002 electricity pylon is a $1 \mathrm{~m}$ wide auxiliary road.

2.2. Geomorphology. Based on the rapid crust uplift during the Quaternary, this area was deeply incised by Yalong River, and steep slopes were formed on both sides of the valley. The geomorphological pattern comprises an erosion terrain inclining from northwest to southeast, which is characterized by deeply incised valleys, intermountain basins, and tectonic depressions [19-22]. The G1002 EPL area is in the middle part of the left bank slope and $200 \mathrm{~m}$ downstream of the dam of the Jinping I Hydropower Station. At the dam site, the river valley is a typical $\mathrm{V}$-shaped canyon with a strike of $\mathrm{N} 25^{\circ} \mathrm{E}$. The elevation of the valley floor is $1590 \sim 1600 \mathrm{~m}$ a.s.l., while the slope shoulder is above $3500 \mathrm{~m}$ a.s.l., with a relative relief of $\sim 1900 \mathrm{~m}$. The slope gradient below and above $1900 \mathrm{~m}$ is $55^{\circ} \sim 70^{\circ}$ and $35^{\circ} \sim 45^{\circ}$, respectively, covered by outcropped marble and colluvial deposits, respectively.
Due to rainfall and gully flood erosion, cross ridges and gullies developed, and the bedrock was exposed (Figure 1). The depth of several well-developed ravines is more than $50 \mathrm{~m}$.

2.3. Meteorological and Hydrological Conditions. The research area has a middle alpine subtropical monsoon climate with rainy and dry seasons. The rainfall during the rainy season (May to October) accounts for $\sim 90 \%$ of the annual rainfall. Based on the data recorded at the Xichang Meteorological Station, the average annual precipitation in this area is $1000.4 \mathrm{~mm}$, the maximum daily rainfall is $100 \mathrm{~mm}$, the maximum hourly precipitation is $30 \mathrm{~mm}$, and the maximum precipitation within $10 \mathrm{~min}$ is $15 \mathrm{~mm}$. Severe convective summer storms are believed to be the dominant causes of floods, especially from June to September. They are limited to small areas and therefore defined as "local storms." These storms can occasionally yield rainfall in excess of $30 \mathrm{~mm}$ in less than an hour and are capable of mobilizing unconsolidated eluvial, diluvial, and colluvial deposits.

When it rains, a small part of rainwater infiltrates colluvial deposits and strongly weathered bedrock, forming phreatic and fissure water, respectively. Due to the steep topography and weak permeable bedrock, groundwater is relatively scarce in the landslide area, and the perched water table on the slope surface is undeveloped. The flows in the gullies are primarily recharged by surface runoff and atmospheric precipitation and present a notable seasonal variation. However, every year, torrential floods in the gullies inundate the toes of the bank slopes within several hours.

2.4. Stratum and Lithology. The strata of the left valley slope from top to bottom consist of metasandstone, silty slate, silty phyllite, marble, and greenschist of the Triassic Zagunao Formation $\left(T_{2-3 z}\right)$. The strike of the stratum is the same as that of the river, and the left bank has a reverse dip slope [19-22]. In the region of the G1002 EPL, from 2100 to $2155 \mathrm{~m}$ in elevation, the bedrock consists of thin-layered Triassic $\left(T_{2-3 z}\right)$ silty slate with bedding dipping into the slope $\left(265^{\circ} \angle 32^{\circ}\right)$ and two sets of joints with $65^{\circ} \angle 65^{\circ}$ and $241^{\circ} \angle 72^{\circ}$ $[19,23,24]$. The outcrops are sporadically distributed on the slope surface and at the bottom of ditches. The loose Quaternary deposits are dense colluvial and debris flow deposits. Colluvial deposits with a thickness of $10-15 \mathrm{~m}$ are distributed on the gentle slope zone and are composed of nonuniform boulders, pebbles, gravel, and silty clay. The size of boulders and pebbles ranges from 50 to $100 \mathrm{~cm}$ and 10 to $30 \mathrm{~cm}$, respectively. The debris flow deposits are distributed in the gullies and are composed of gravel soil with a depth of 4-5 m.

2.5. Geotectonic Activity and Seismicity. The research area is located within the Yajiang-Daocheng block (Figure 2), which is dominated by overall uplift with insignificant differential activities. The nearest fault is the Jinpingshan-Xiaojinhe fault 


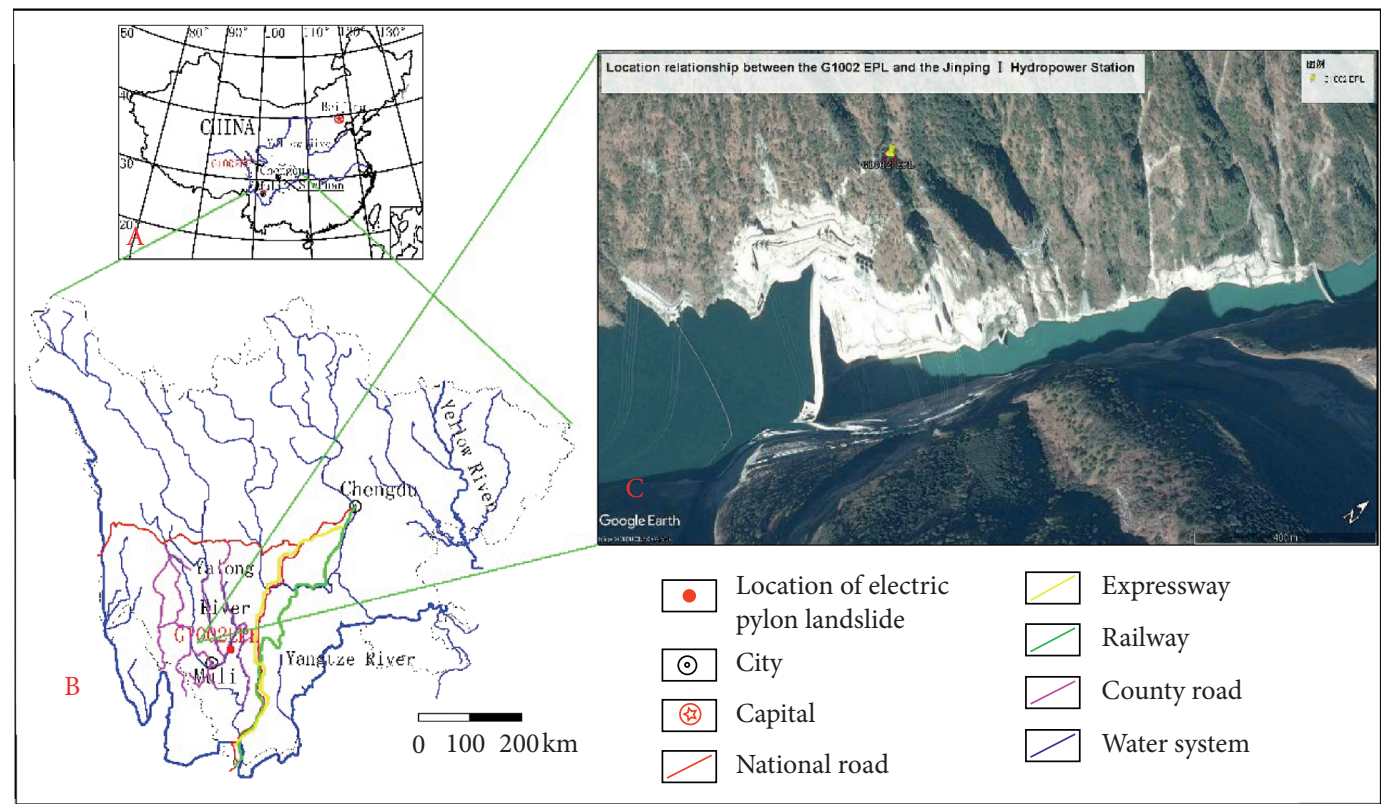

FIGURE 1: Locations of the G1002 electricity pylon landslide and Jinping I Hydropower Station (๔ Google Maps).

with a general $\mathrm{N} 30^{\circ}-40^{\circ} \mathrm{E}$ strike and $\mathrm{NW} 70^{\circ}-85^{\circ}$ dip [19-21, 23]. Based on the dating of samples of the Jingjiang fault, there has been no activity since the middle Pleistocene (170 000-380 $000 \mathrm{yr}$ ).

According to the seismic ground motion parameter zonation map of China [25], the seismic intensity in the Jinping I Hydropower Station is VII, and the peak ground acceleration (PGA) is $104.3 \mathrm{gal}$ with a response spectrum period of $0.45 \mathrm{~s}$. From 1944 to the present, there are no earthquakes with surface-wave magnitude $(\mathrm{Ms}) \geq 6$ in this region. Therefore, the research area is classified as a structural stability zone $[19,23]$.

2.6. Anthropogenic Activities. The engineering activities at the Jinping I Hydropower Station include the excavation of abutment slopes, underground caverns, and foundation of electricity pylons [26, 27]. Based on the nearby seismic monitoring station, 162 and 11 microseismic events greater than magnitude II and III, respectively, occurred from January 1 to December 30, 2012 [28]. All seismic energies mainly originated from rock fractures related to the large-scale excavation of the dam abutment slope and detonations for the construction of underground caverns [19-21, 23, 29]. Multiple microseismic events may deteriorate the integrity of the shallow soil and generate cracks on slopes. The construction of the pile foundation resulted in the formation of unfavorable interfaces between the C-pile and ambient soil masses. When microseismic waves diffract through these interfaces, reflection and refraction affect the stability of the soil masses $[28,30]$.

\section{Basic Characteristics and Stability Evaluation of the G1002 EPL}

3.1. Basic Characteristics of the G1002 Electricity Pylon Landslide. Based on the field investigation and topographic mapping, the G1002 EPL can be divided into three zones: sliding zone (deposition and source zones), tractive deformation zone, and potential horizontal unstable zone (Figures 3 and 4). The slope gradient and elevation of the sliding zone are $25^{\circ}-55^{\circ}$ and $2100-2155 \mathrm{~m}$ a.s.l., respectively, with a relative height difference of $55 \mathrm{~m}$ (Figures 5 and 6). The longitudinal length is $63.3 \mathrm{~m}$, the transverse width is $50 \mathrm{~m}$, and the plane area is $1763.97 \mathrm{~m}^{2}$. The thickness of the landslide deposits ranges from 3 to $8 \mathrm{~m}$, and the total accumulative volume of the deposits is $8820 \mathrm{~m}^{3}$. The exposed sliding plane (Figures 4 and 5) is the interface between the colluvial soil and the bedrock and near-planar with the slope of $39^{\circ}$. The composition of landslide deposits is silty clay, fine rubble, and gravel, which is the same as that of residual soil masses in the rear area of the main scarp. These two phenomena indicate that the G1002 EPL is a tractive translational sliding along the soil-bedrock interface. Because the narrow and steep gully bank perpendicularly hampered the landslide (Figure 3), the deposits were stable in the absence of flood scouring.

In the tractive deformation zone, the terrain is steep with a slope gradient and elevation ranging from $40^{\circ}$ to $45^{\circ}$ and 2135 to $2172 \mathrm{~m}$ a.s.l., respectively. Based on the site investigation, a notable tensile crack with $13 \mathrm{~m}$ in length, $0.2-0.6 \mathrm{~m}$ in width, and $1 \mathrm{~m}$ in maximum depth appeared $3 \mathrm{~m}$ away from the D-pile of the G1002 electricity pylon (Figure 3(b)). By October 30, 2012, the residual colluvial soil in the vicinity of the D-pile had sunk by $1.2 \mathrm{~m}$, exposing the pile foundation (Figure 3(c)). It was inferred that the tractive deformation zone would subsequently fail due to precipitation infiltrating the residual soil along the crack.

The potential unstable zone was mainly bounded by the ridge on the right side of the G1002 electricity pylon and the outline of the tractive deformation zone. The slope gradient and elevation of this zone are $30^{\circ}-55^{\circ}$ and $2172-2180 \mathrm{~m}$ a.s.l., respectively. Based on the headward erosion of the surface 


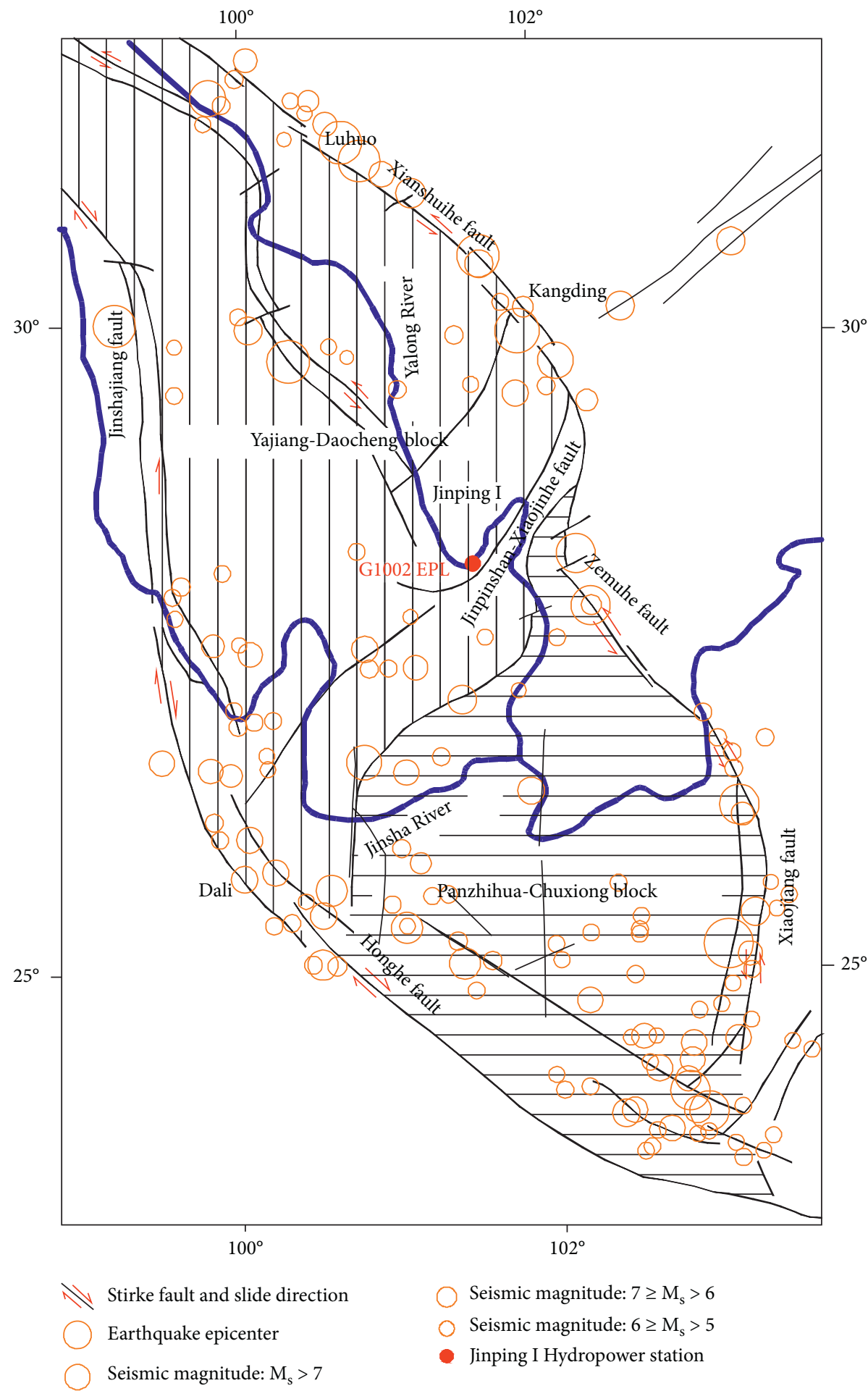

FIgURE 2: Regional geological structure and historical earthquakes that occurred close to the Jinping I Hydropower Station (modified after Qi et al. [23]).

runoff, the residual colluvial deposits would become unstable, resulting in the destruction of the foundation of the G1002 electricity pylon. Therefore, it is necessary to calculate the stability coefficient of the tractive deformation zone and potential unstable zone and design reasonable countermeasures to protect the electricity pylon.
3.2. Failure Mechanism of the G1002 Electricity Pylon Landslide. Numerous research studies indicated that shortterm heavy rainfall and long-term preceding rainfall are two important processes for shallow accumulation landslides [31-34]. Wieczorek [35] described that colluvium landslides induced by rainstorms with relatively low 


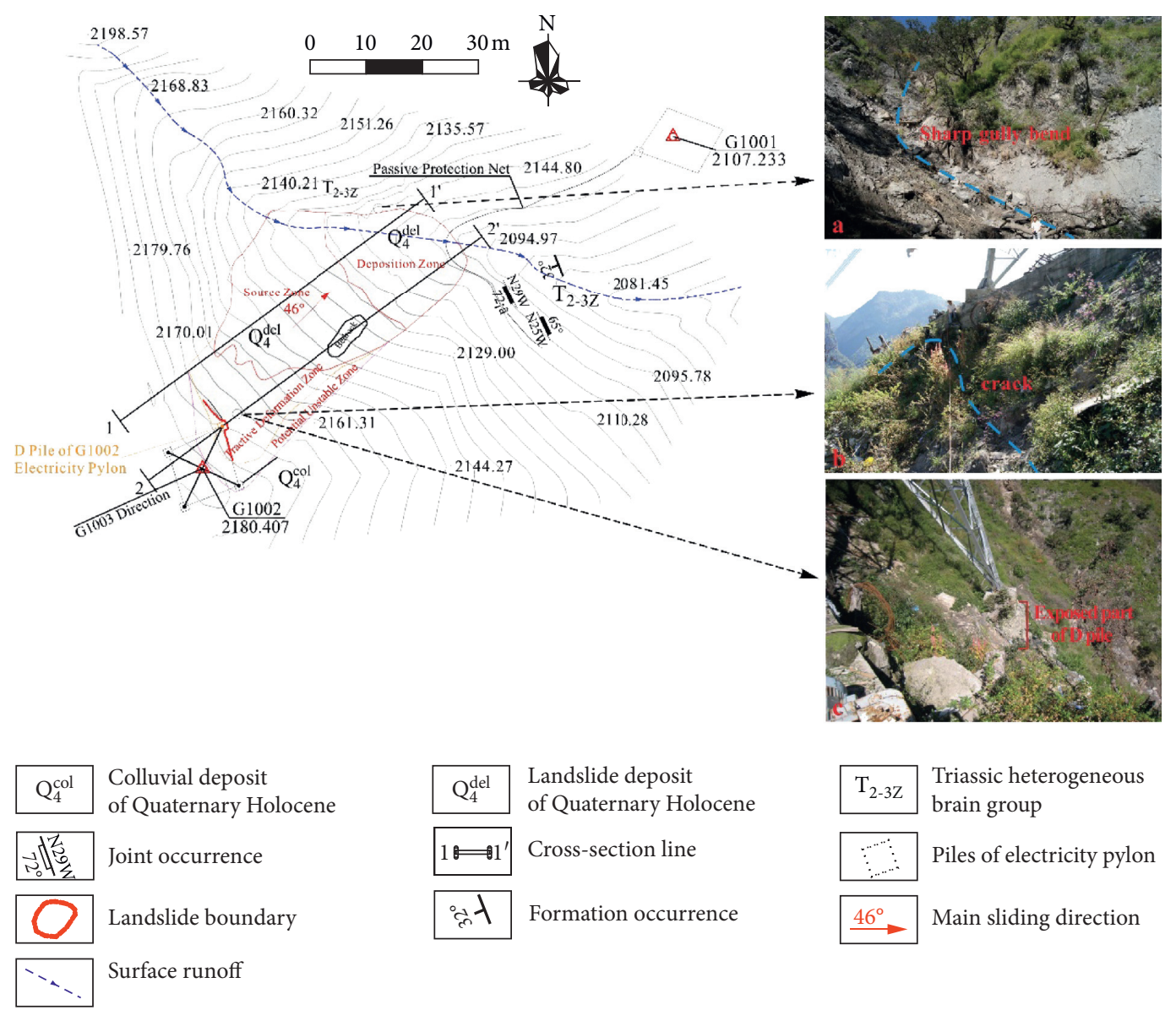

FIgURE 3: Geological engineering plan and the features of the G1002 EPL. The flow direction (blue dashed line) changed from $291^{\circ}$ to $275^{\circ}$ with a deflection angle of $16^{\circ}$ at the concave gully bend, where the toe of the slope could suffer the erosion and scour of the floods. (a) The G1002 EPL blocked the gully. There were wide slate outcrops on the left side slope (covered by the flexible protection net). (b) The tractive deformation zone at the rear of the main scarp of the G1002 EPL. A deep tensile crack threatened the foundation of the G1002 electricity pylon. (c) The exposed D-pile of the G1002 electricity pylon.

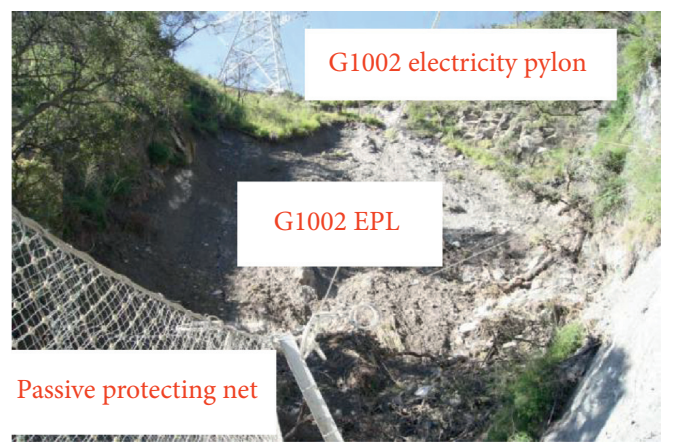

FIgUre 4: Sliding zone of the G1002 EPL (towards southwest). The residual soil masses in the rear area of the main scarp indicated that the sliding source consists of silty clay, fine rubble, and gravel derived from silty slate. Residual soil masses covered with vegetation would fail by the retrogressive erosion of rainfall.

intensity (less than $10 \mathrm{~mm} / \mathrm{h}$ ) preceded by long antecedent rainfall. Cannon and Ellen [36] described several colluvium landslides by short, high-intensity rainfall at the end of a sustained period of low-intensity rainfall and gave a critical warning threshold.
Correspondingly, the failure mechanisms of rainfallinduced landslides include the hydraulic characteristics of the source masses [37-43], heterogeneity of pore systems $[44,45]$, variation of the groundwater pressure [46-50], negative and positive pore water pressures [31, 50-54], matric suction [55-57], ground water level fluctuation $[58,59]$, seepage variation [60-62], and basal erosion by ingress water [41, 63-65]. However, lateral scour and erosion of the flood are rarely reported for mountainous regions with well-developed gullies [66].

Previous feasibility research and analysis of the geological conditions of the research area showed that the possibility of geohazards is very small. However, the excavated volume of $5.933 \times 10^{6} \mathrm{~m}^{3}$ including large underground caverns and the left dam abutment slope of $60 \mathrm{~m}$ height and $300 \mathrm{~m}$ width was huge $[24,26,27]$, which can significantly affect the stress balance and produce stress redistribution $[67,68]$. As a result, many unloading fissures in the shallow rock layers were formed, and the rock joints were relaxed. According to the data of the field mechanics tests before and after excavation, the internal friction angle and cohesion of the structural planes at the dam abutment slope reduced 


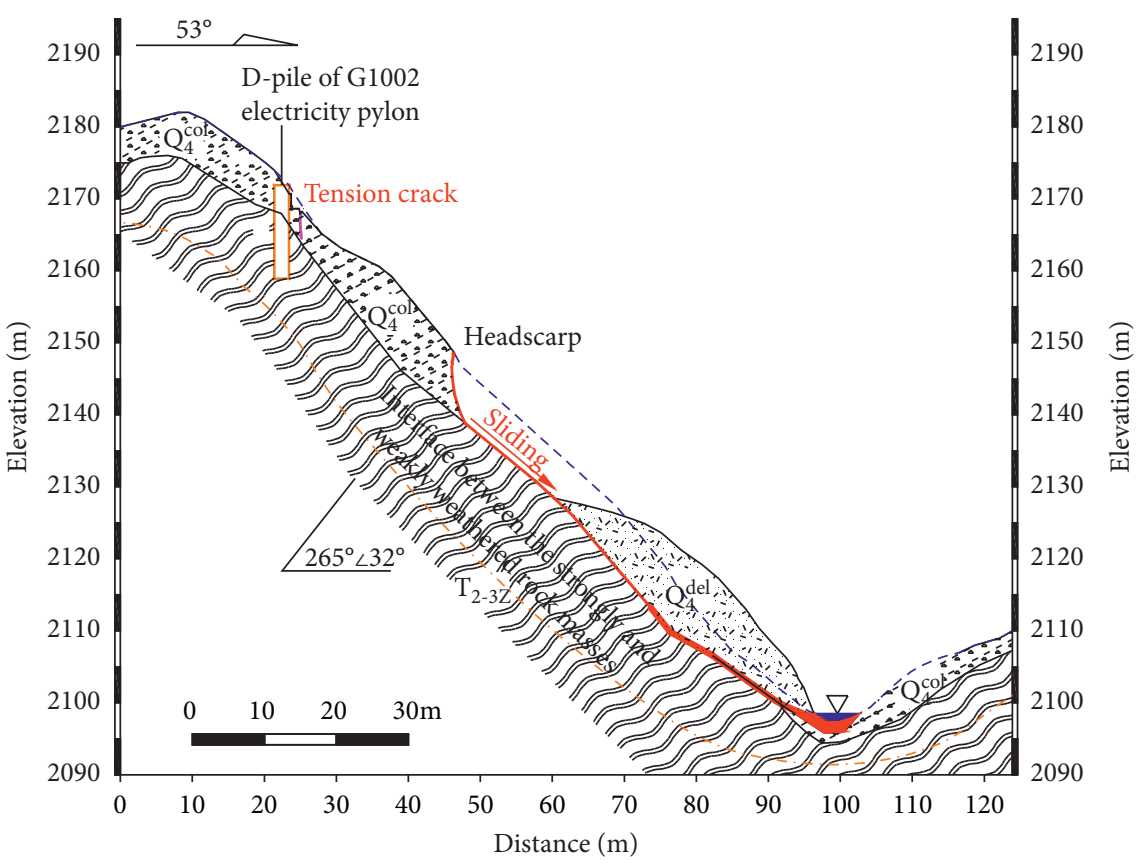

\begin{tabular}{|c|c|c|c|}
\hline$\approx$ & Silty slate & $\underline{\underline{\nabla}}$ & Water level \\
\hline I & $\begin{array}{l}\text { Triassic heterogeneous } \\
\text { brain group }\end{array}$ & \begin{tabular}{|l|} 
Q col \\
\end{tabular} & $\begin{array}{l}\text { Colluvial deposit } \\
\text { of Quaternary Holocene }\end{array}$ \\
\hline $\mathrm{Q}$ & $\begin{array}{l}\text { Landslide deposit } \\
\text { of Quaternary Holocene }\end{array}$ & $265^{\circ} \angle 32^{\circ}$ & Formation occurrence \\
\hline 5 & Gravel soil & & Extrapolated erosion area \\
\hline G & Landslide deposit & & Tension crack \\
\hline
\end{tabular}

Figure 5: Geological cross-section $\left(2-2^{\prime}\right)$ profile of the G1002 EPL. The erosion at the concave slope toe induced a retrogressive sliding mode.

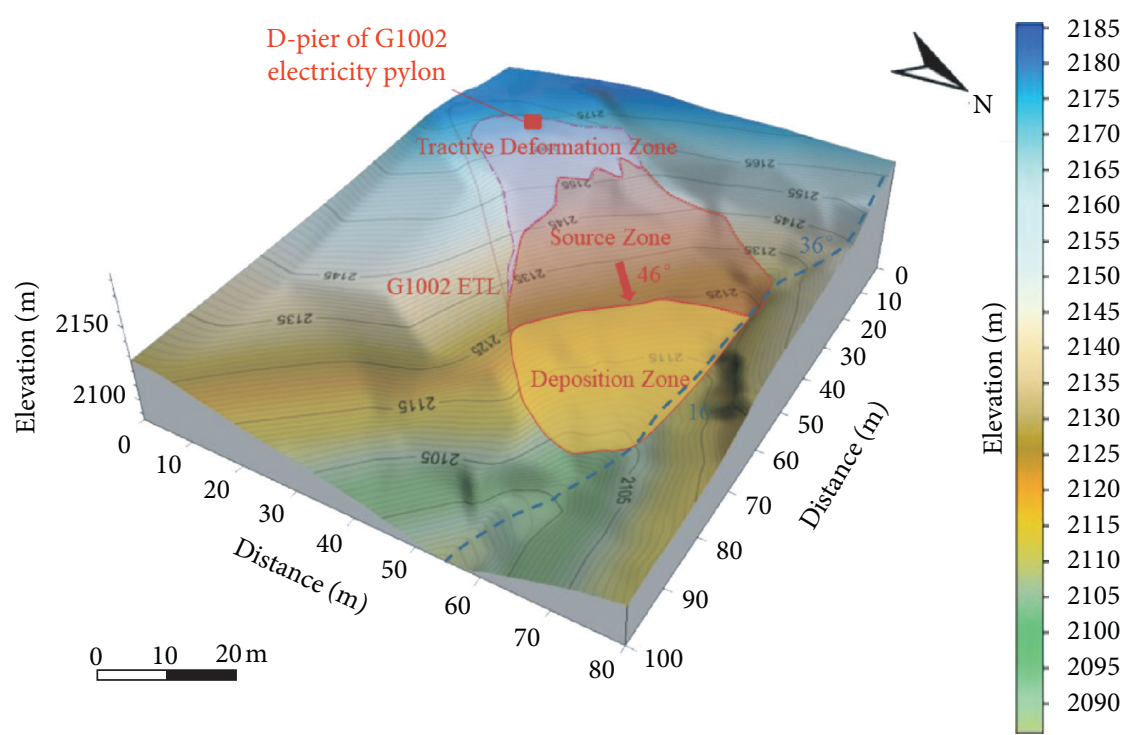

Figure 6: DEM model of the G1002 EPL. The sudden decrease in the bed gradient from $36^{\circ}$ to $16^{\circ}$ at the sharp gully bend reduced the momentum of the flood and could produce turbulence flow, which would intensify the lateral erosion.

from $35^{\circ}$ to $24^{\circ}$ and from $1.40 \mathrm{MPa}$ to $0.1 \mathrm{MPa}$, respectively. The longitudinal wave velocity of rock masses reduced from $6,000 \mathrm{~m} / \mathrm{s}$ to $3,000 \mathrm{~m} / \mathrm{s}$. Moreover, from June 2009 to May
2011, there were more than 1000 microseismic events in the dam abutment area [19-21]. From January 1 to December 30, 2012, there were 162 microseismic events greater than 
magnitude II and 11 ones greater than magnitude III [28]. In addition, the continuous detonation and the foundation excavation of the G1002 electricity pylon (section area of $2 \times 2 \mathrm{~m}$ and depth of $13 \mathrm{~m}$ ) could change the mechanical properties of soil masses and further promote slope deformation [69].

Comparing with stable nearby colluvium slopes with the same material composition but steeper topography (approximate $53^{\circ}$ ), the heavy precipitation does not seem to be a decisive factor. Based on the average values of the daily rainfall records of Muli and Yanyuan counties, the rainfall which occurred on August 29 and 30 is very low and in the normal range of fluctuation (Figure 7). Undeniably, the temporal and spatial distribution of precipitation in mountainous areas is uneven. Because there was no rainfall monitoring station at the Jinping I Hydropower Station, based on the announcement of the Ministry of Land and Resources, the rainfall on August 29 and 30, 2012, reached once-in-a-century. Considering the retrogressive mode of the G1002 EPL (Figures 4 and 5), the superimposed effect of the lateral erosion of gully flood and soil saturation induced by long-term and low-intensity preceded precipitation indeed played a major role on the occurrence of the G1002 EPL. More significantly, the strong changes in the inclination and gradient of the gully bed created areas prone to landslides under superimposed conditions such as concave banks and cascades [66].

Based on the aforementioned analysis, the evolution of the G1002 EPL can be summarized as follows: (1) the continuous detonation and the large-volume excavation produced relaxation and unloading of structural planes and reduced the mechanical properties of rock and soil masses; (2) long-term and low-intensity preceded precipitation saturated and weakened the colluvial soil, especially at the toe of the slope; (3) the flood in the gully eroded the saturated soil, and small cracks appeared in the upper soil (Figure 8(a)); (4) with the increase in the erosion, the upper soil lost the foot support and began to creep along the interface between the colluvial soil and the impermeable bedrock; (5) when the shear strain of the creep belt was exacerbated to beyond the threshold, the slopes failed (Figure 8(b)); and (6) due to the retrogressive erosion, the sliding zone expanded backward (Figure $8(\mathrm{c})$ ). When the intensity of the precipitation weakened and the flood level decreased, the landslide ceased accordingly.

3.3. Stability Evaluation of the Residual Colluvial Soil. Considering the long-term retrogressive erosion of rainfall, the stable state of the residual colluvial soil in the tractive deformation zone must be analyzed accurately. In China, due to its conceptual clarity, versatility, and simple calculation, the limit equilibrium method is widely used in slope survey and design and is specified as the stability evaluation method to be used in general by the China Geological Survey [70]. It should be noted, however, that this method is not suitable when dealing with some special landslides, such as lateral spreads, diffuse landslides, plastic flow, and the rockslide undergoing sudden brittle fracture [71]. The crucial prerequisites of this method are that the sliding plane has been determined, the soil of the rupture surface observes Mohr-Coulomb failure criterion, and the sliding body is coherent during sliding [72]. According to the geological field surveys and topographical mapping, the G1002 EPL with its planar sliding surface maintains coherence during the sliding stage. Hence, the limit equilibrium method was considered suitable for determining the stability of the residual colluvial soil, and the calculation accuracy was sufficient to meet the needs of engineering design. The stability coefficient, also known as the factor of safety against sliding [73], is the ratio of the shear resistance to the shear force of the entire sliding plane. If the shear strength is greater than the shear force (stability coefficient $>1$ ), the slope is stable. On the contrary, if the shear strength is less than the shear force (stability coefficient $<1$ ), the slope will slide.

The $2-2^{\prime}$ cross section in the main sliding direction was selected as the calculation profile. Considering the failure mode of the G1002 EPL and the crack, the most potential sliding plane of the tractive deformation zone is the interface between the colluvial soil and the bedding rock (Figure 9). The shear strength parameters of the rock and soil masses were ascertained by site mechanics tests (Table 1). The stability coefficients of the residual soil masses are, respectively, calculated under three scenarios (Table 2 and Figure 9). The results indicate that the residual soil will be unstable under rainfall conditions (stability coefficient $=0.98<1$ ), directly affecting the safety of the G1002 electricity pylon.

To verify the stability calculation results, a numerical model using finite element software FLAC3D was established to simulate the displacement and shear strain distribution of the slope under the adverse rainfall condition. The simulation results show that the maximum displacement occurs at the front of the residual masses, reaching $2.569 \mathrm{~m}$, and the shear strain increment at the bottom of the residual masses is $120 \%$ (Figure 10). This indicates that the residual masses will fail and slide along the interface during future rainfall scenarios.

\section{Mitigation and Control Countermeasures}

Because the residual soil masses were unstable under rainfall conditions, countermeasures were designed to stabilize the tractive deformation zone close to the $\mathrm{D}$-pile rather than controlling the whole landslide. Based on the site conditions and engineering experience, the combination of anchor cables with lattice frame beams and slide-resistant piles was proposed. Because the traffic was very inconvenient and there was only one $1 \mathrm{~m}$ wide auxiliary road to the G1002 electricity pylon, the transport of large engineering machinery and heavy construction material was very difficult. Considering that large and deep piles in the strongly weathered silty slate could disturb the vulnerable slope, which might be costly and time-consuming, the scheme including slide-resistant piles was abandoned. On the contrary, because anchor cables with lattice frame beams are suitable for light machinery and operation, they were 


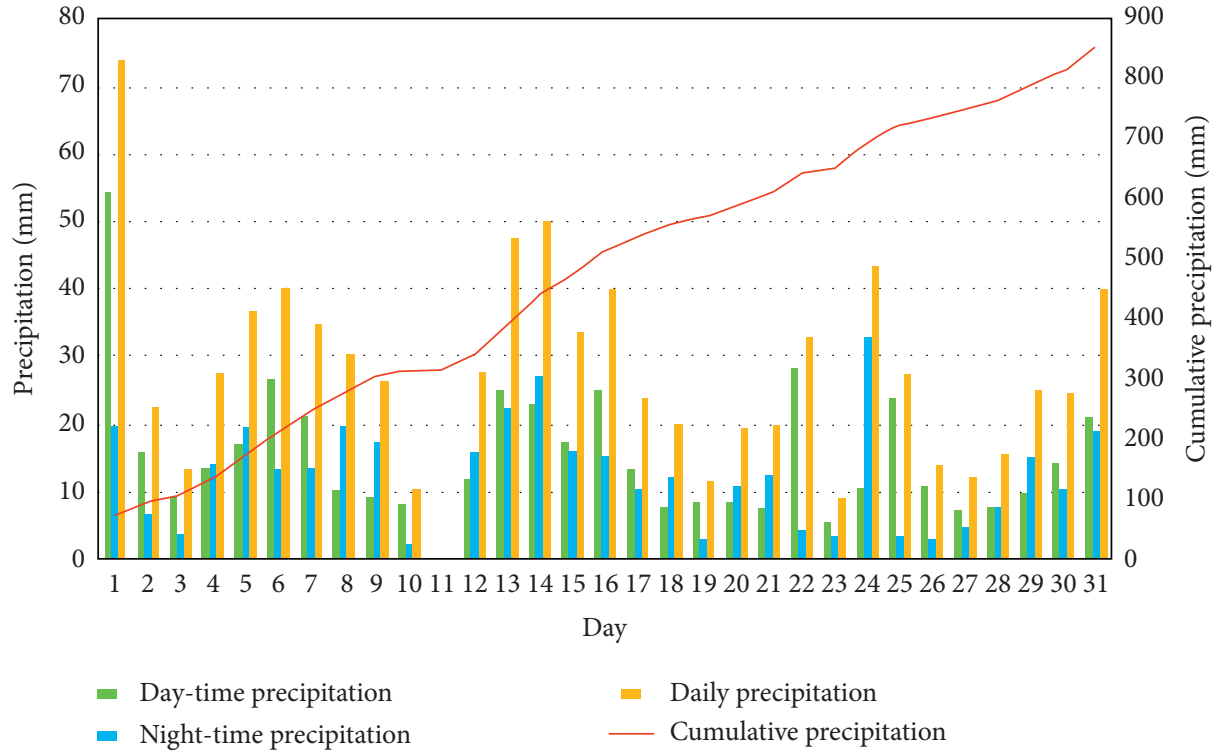

Figure 7: Daily and cumulative precipitations in the research area in August 2012. The cumulative precipitations in August reached $855.7 \mathrm{~mm}$ (according to the Muli and Yanyuan Meteorological Bureau).

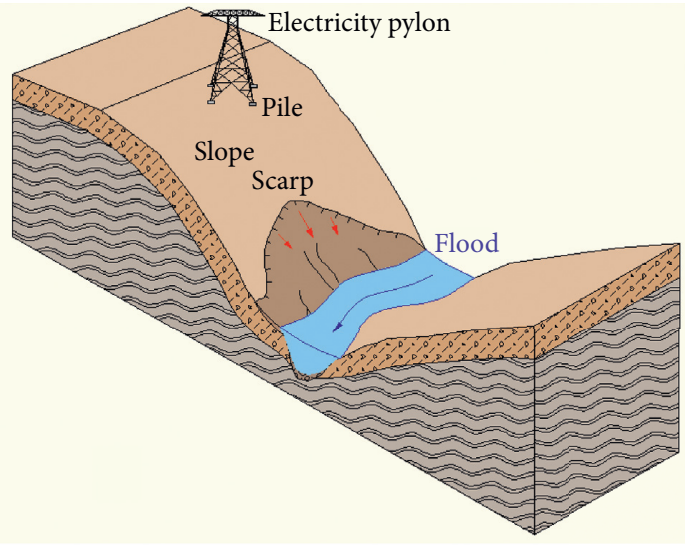

(a)

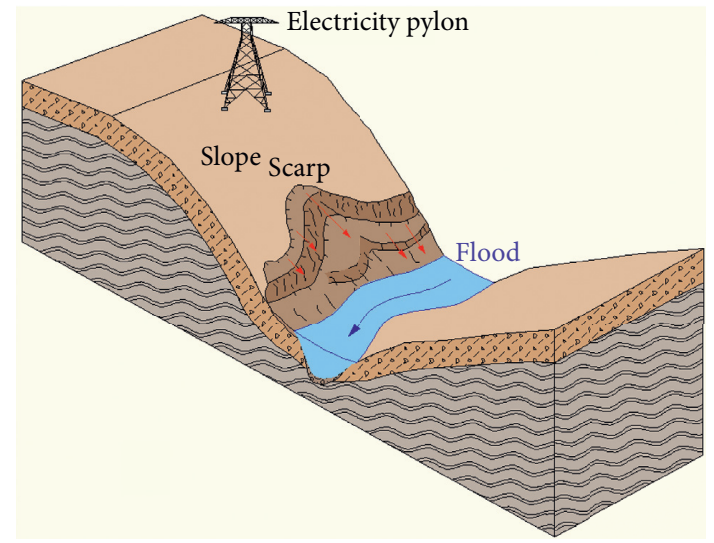

(b)

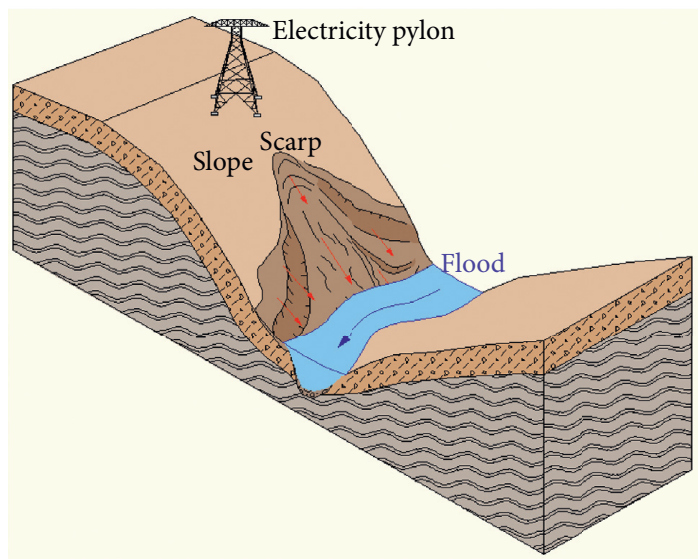

(c)

Figure 8: Evolution of the G1002 EPL. (a) Scouring and erosion on a concave bank due to flood, which produces cracks. (b) The slope deposits slip retrogressively and block the gully. (c) The dammed deposits breach, and the landslide occurs. 


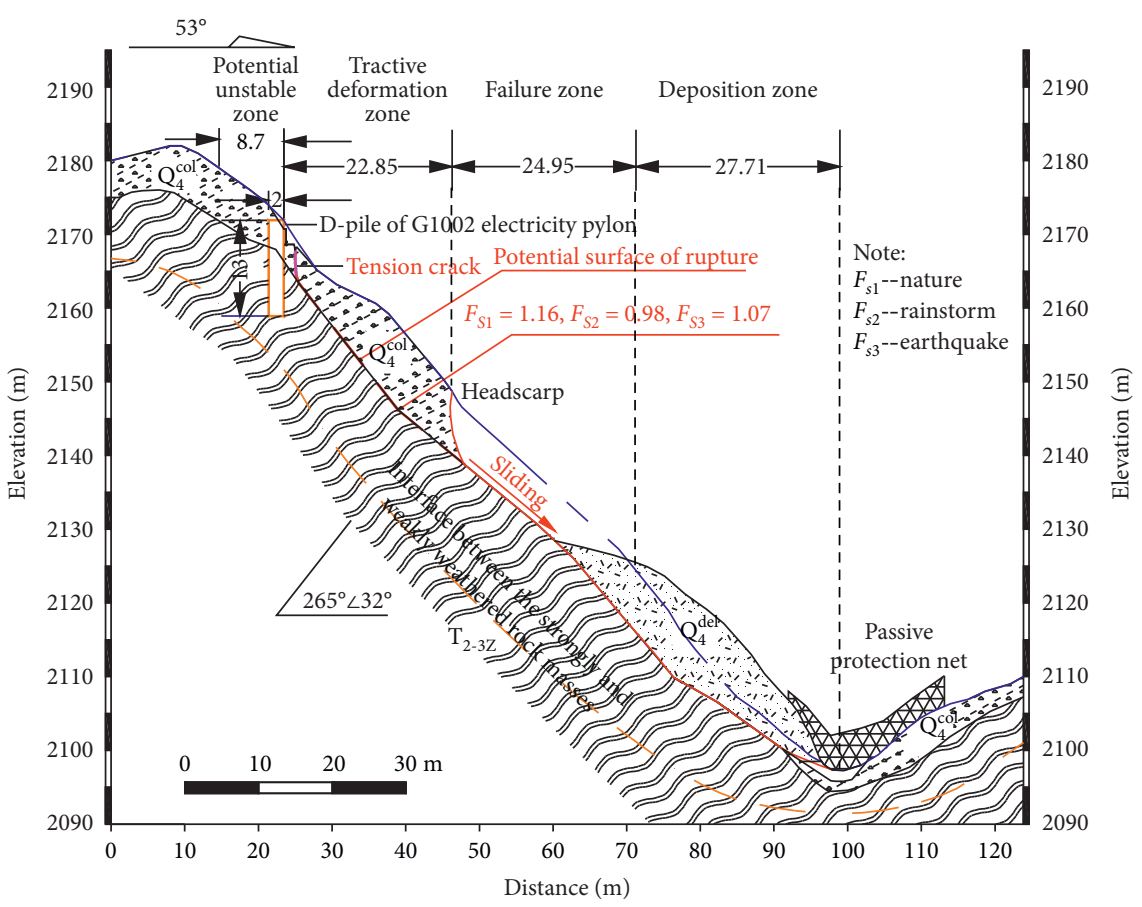

\begin{tabular}{|c|c|}
\hline हn & Silty slate \\
\hline $\mathrm{T}_{2-3 \mathrm{Z}}$ & $\begin{array}{l}\text { Triassic heterogeneous } \\
\text { brain group }\end{array}$ \\
\hline $\mathrm{Q}_{4}^{\mathrm{del}}$ & $\begin{array}{l}\text { Landslide deposit } \\
\text { of Quaternary Holocene }\end{array}$ \\
\hline$\left[\begin{array}{l}0 \\
0\end{array}\right.$ & Gravel soil \\
\hline & Landslide deposit \\
\hline
\end{tabular}

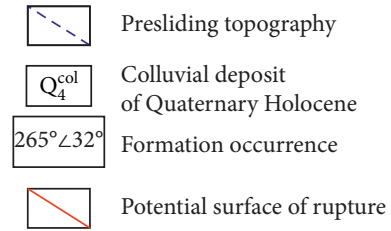

FIGURE 9: Stability coefficients of the residual soil masses under different scenarios (2-2' cross section).

TABle 1: Physical and mechanical parameters of the rock and soil masses.

\begin{tabular}{|c|c|c|c|c|c|}
\hline \multicolumn{2}{|c|}{ Parameters of source masses } & Dry or saturation & Density $\left(\mathrm{kg} / \mathrm{m}^{3}\right)$ & Cohesion $(\mathrm{kPa})$ & Internal frictional angle $\left({ }^{\circ}\right)$ \\
\hline Natural state & Soil & $\mathrm{D}$ & 2120 & 30.0 & 28.0 \\
\hline Rainfall state & Soil & $S$ & 2280 & 22.0 & 24.0 \\
\hline Natural state & Strongly weathered rock mass & $\mathrm{D}$ & 2500 & 300.0 & 33.0 \\
\hline Rainfall state & Strongly weathered rock mass & $S$ & 2620 & 200.0 & 29.0 \\
\hline
\end{tabular}

TABLE 2: Stability coefficients of the residual soil under different scenarios.

\begin{tabular}{lccc}
\hline Scenarios & Stability coefficient & Residual thrust $(\mathrm{kN} / \mathrm{m})$ & Stable state \\
\hline Natural & 1.16 & 0 & Stable \\
Rainfall & 0.98 & 381.89 & Unstable \\
Earthquake & 1.07 & 187.57 & Stable \\
\hline
\end{tabular}

recommended to strengthen and control the residual masses in the tractive deformation zone.

In the design scheme, lattice frame beams casted with C30 concrete cover the whole tractive deformation zone and a part of the sliding zone (Figures 11 and 12). The 8 horizontal beams with a $3 \mathrm{~m}$ separation distance were $30-36 \mathrm{~m}$ in length. The vertical ribs with a $4 \mathrm{~m}$ separation distance were $12 \mathrm{~m}$ in length. The area of all beams and ribs was $50 \times 60 \mathrm{~cm}$.
The intersection point between a beam and vertical rib was a borehole with a diameter of $130 \mathrm{~mm}$ in which the anchor cable was placed. A total of 55 anchor cables with a length of $8 \mathrm{~m}$ were inserted into the weakly weathered bedrock (Figure 13). The $30 \mathrm{~m}$ and $20 \mathrm{~m}$ anchor cables were alternatingly arranged to avoid linear rupture at the bottom of the borehole (Figure 13). Each anchor cable consisted of seven $\phi s 15.2$ steel strands. The design anchoring force 


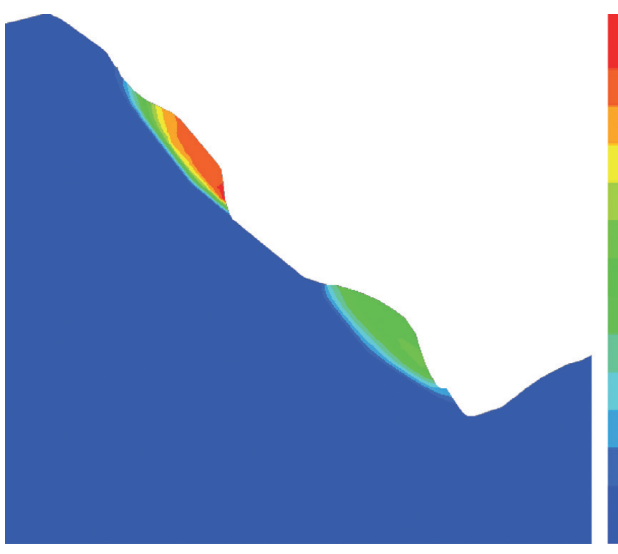

(a)

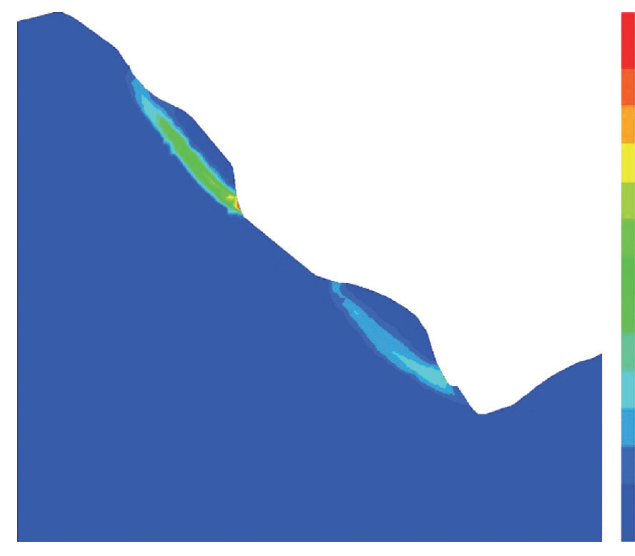

$.2052 E+00$

$1.2000 E+00$

$1.1000 E+00$

$1.0000 E+00$

$9.0000 E-01$

$8.0000 E-01$

$7.0000 E-01$

$6.0000 E-01$

$5.0000 E-01$

$4.0000 E-01$

$3.0000 E-01$

$2.0000 E-01$

$1.0000 E-01$

$4.0492 E-05$

(b)

FIgURE 10: Numerical simulation results for the residual soil under rainfall conditions $\left(2-2^{\prime}\right.$ cross section). (a) Contour of the outward displacement. (b) Contour of the shear strain increment.

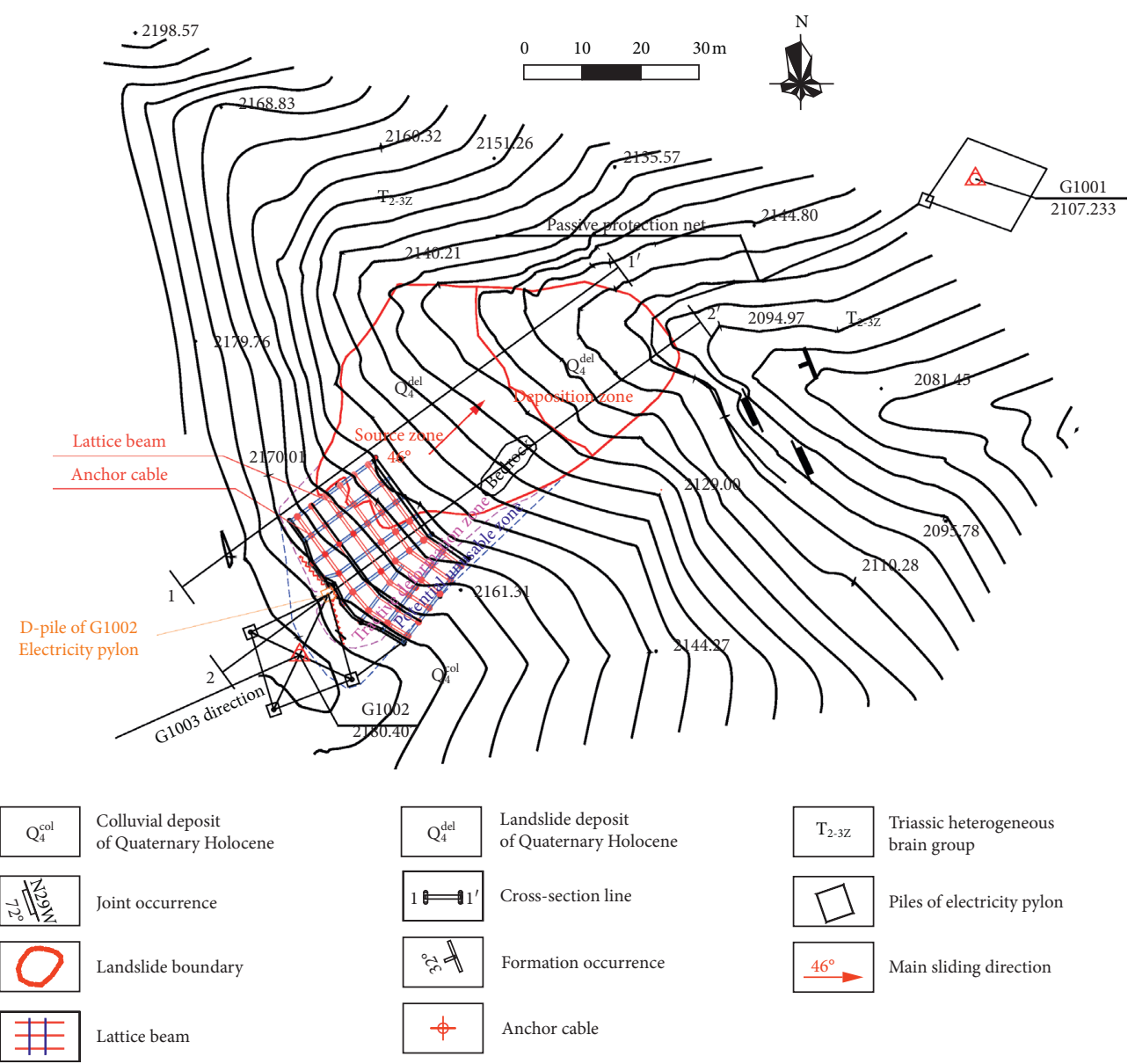

FIgURE 11: Plan layout of the anchor cables with lattice frame beams to control the residual masses of the G1002 EPL. The spaces between frame beams are filled by M10 mortar rubble concrete with a thickness of $0.3 \mathrm{~m}$ to slow down future weathering.

reached up to $1000 \mathrm{kN} / \mathrm{m}$. Under stress relaxation, the working anchoring force could reach $700 \mathrm{kN} / \mathrm{m}$, that is, a larger value than the residual thrust of $381.9 \mathrm{kN} / \mathrm{m}$. The $1: 1$ cement mortar with a water-cement ratio of 0.40 was adopted as the grouting material, ensuring strength $\geq 30 \mathrm{MPa}$.

Except for these measures, crack sealing was carried out sequentially to fill the tensile crack. The crack was cleaned 


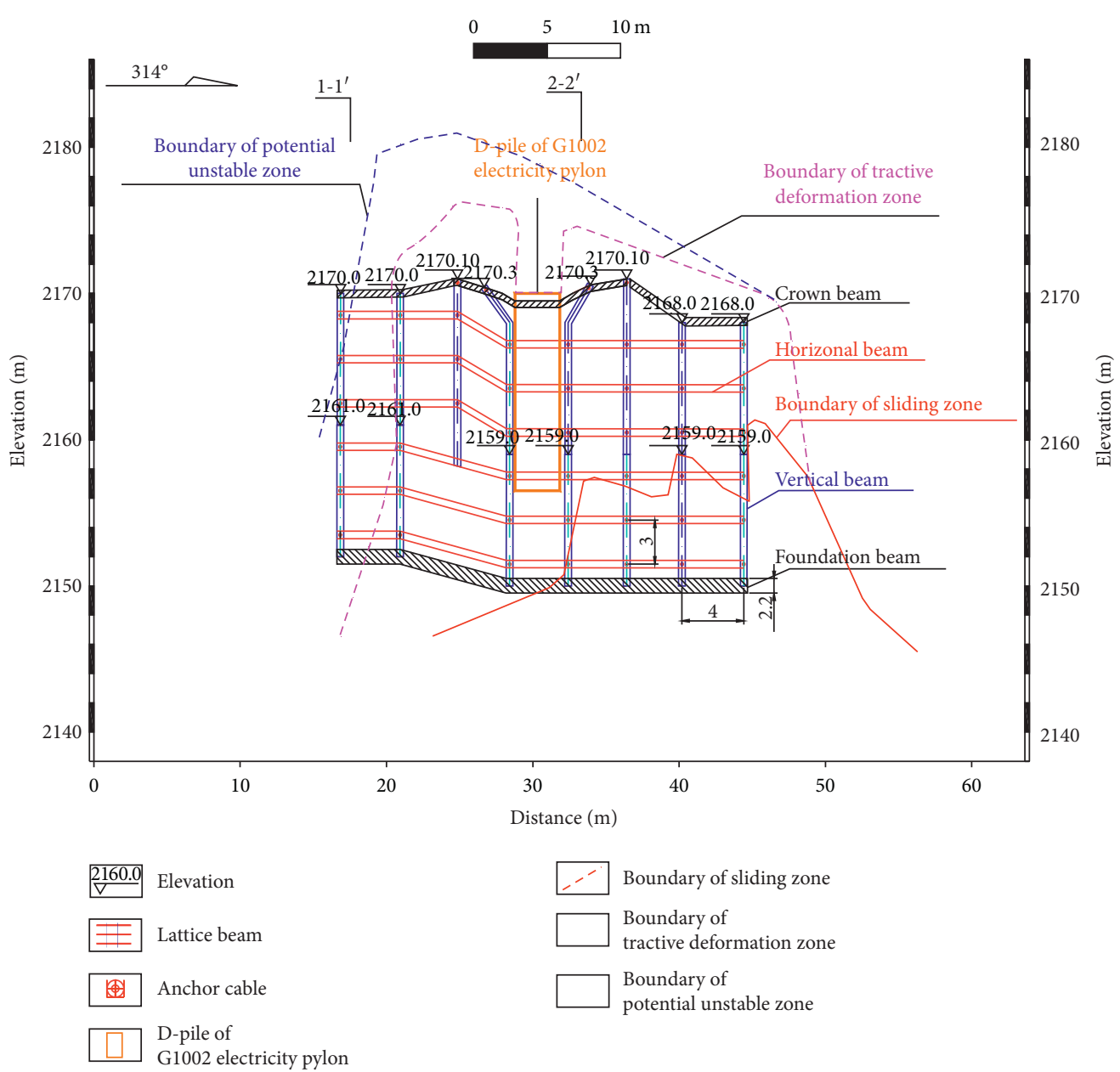

FIGURE 12: Vertical layout and protection range of the lattice frame beams.

before sealing and then was filled with a mixture of quicklime and clay with a ratio of 1 and 10 and compacted.

To verify the effectiveness of the reinforcement of the anchor cables, a numerical simulation was carried out to predict the displacement and shear strain increment under the adverse rainfall condition. The physical and mechanical parameters of the colluvial soil and anchor cable are listed in Tables 1 and 3. As shown in Figure 14, after the mitigation measures, the residual soil masses are stable under rainfall conditions.

\section{Discussion}

Many large hydropower stations and corresponding electricity transmission pylons have already been located in Southwest China, and there will be more of them in the future. Therefore, the safety of the electricity pylon is particularly important. Previous engineering experiences have indicated that stable ridges are highly suitable for the foundation of electricity pylons. However, the relaxation and unloading effect induced by the large-volume excavation of the dam abutment slopes and multiple detonations could affect the slope stability. Especially, the blasting vibration effect of the continuous detonation on the interfaces between the pile foundation of electricity pylons and the surrounding soils can produce tensile cracks. Moreover, scouring and erosion of the concave bank by floods are important processes triggering shallow landslides in gullies, which are rarely considered during the selection of the initial construction site. Therefore, exploration for the failure mechanism and mitigation work are particularly important. Based on the case study of the G1002 EPL, several site selection suggestions for electricity pylons are proposed in the following:

(1) The risk evaluation of shallow landslides in gullies under consideration of the blasting vibration and lateral erosion should be carried out prior to the electricity pylon construction. The fissures and cracks need to be sealed at all to avoid surface water infiltrating into the foundation region of the electricity pylons. Advanced reinforcement for the interfaces between deposits and bedrock, as well as the slope toe, should be conducted before the excavation of the electricity pylon foundation.

(2) During periods of flooding, the turbulence flow and lateral erosion can be produced at the sharpchanging position of the strike and the gradient of narrow, deep-incised gullies, which could destabilize the shallow deposits. Johnson and Rodine [74] 


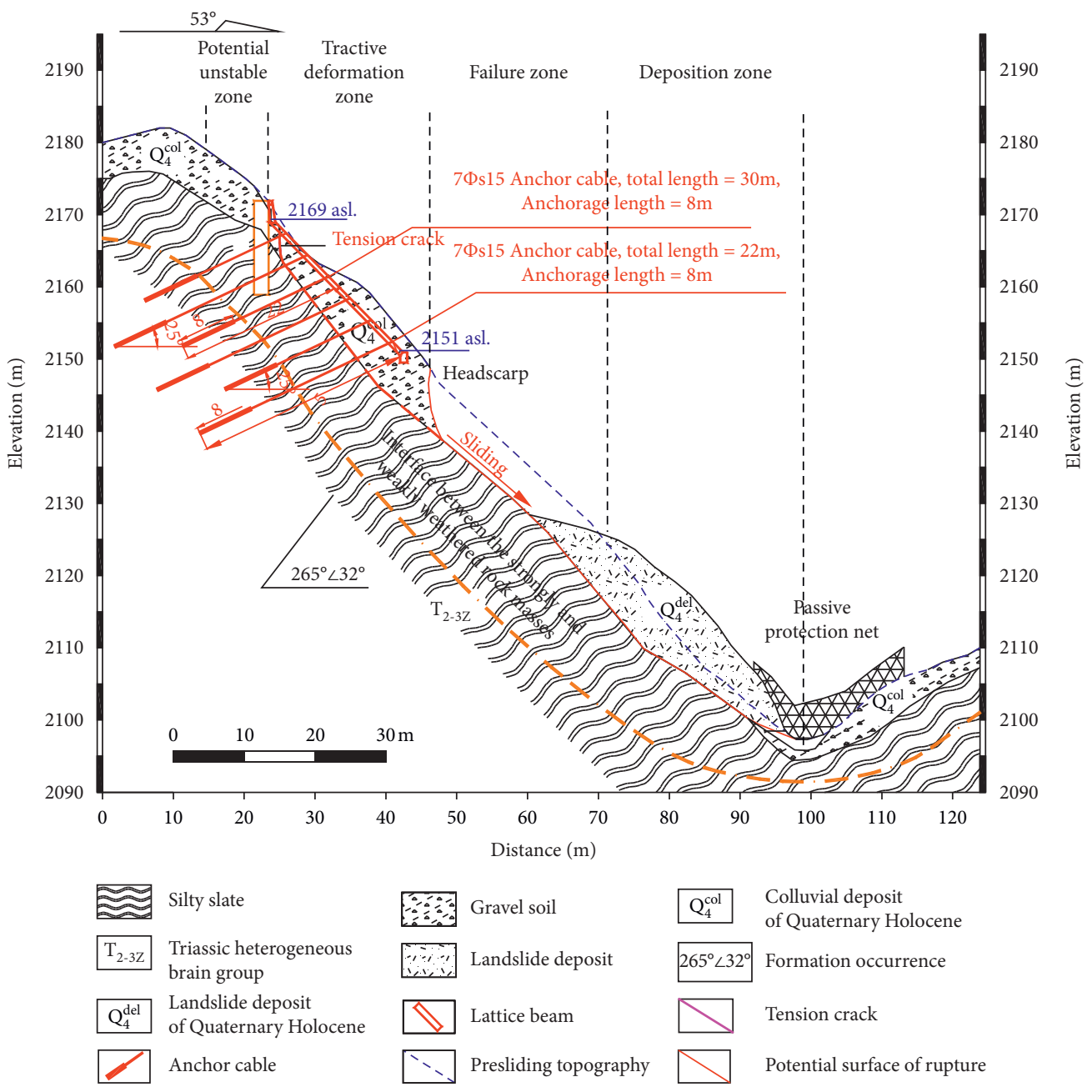

Figure 13: Anchor cables with lattice frame beams to control the residual masses ( $2-2^{\prime}$ cross section). The $30 \mathrm{~m}$ and $22 \mathrm{~m}$ anchor cables with $8 \mathrm{~m}$ anchorage length are alternatingly installed. Each anchor cable consists of $7 \phi s 15.2$ steel strands with high strength and low relaxation. The design load of the anchor cables is $1000 \mathrm{kN} / \mathrm{m}$, and the working load can reach $700 \mathrm{kN} / \mathrm{m}$.

TABle 3: Design parameters of anchor cables.

\begin{tabular}{lccccc}
\hline $\begin{array}{l}\text { Borehole } \\
\text { diameter }(\mathrm{mm})\end{array}$ & $\begin{array}{c}\text { Anchor } \\
\text { diameter }(\mathrm{mm})\end{array}$ & $\begin{array}{c}\text { Elasticity modulus } \\
\text { of cement }(\mathrm{GPa})\end{array}$ & Friction angle of cement $\left(^{\circ}\right)$ & $\begin{array}{c}\text { Cohesion of cement } \\
(\mathrm{kPa})\end{array}$ & $\begin{array}{c}\text { Tensile strength } \\
(\mathrm{kPa})\end{array}$ \\
\hline 65.0 & 20.8 & 200 & 35.0 & 3180 & 1430 \\
\hline
\end{tabular}

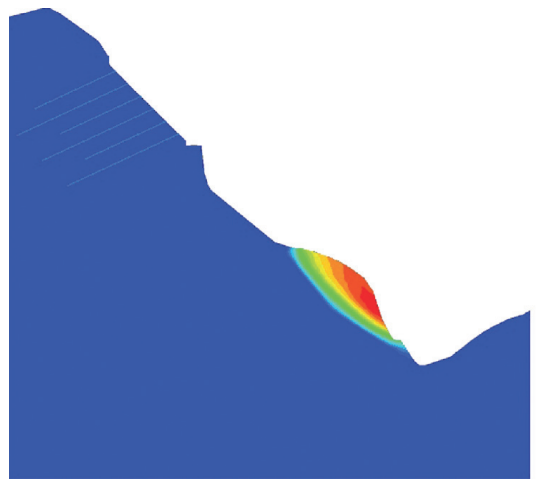

(a)

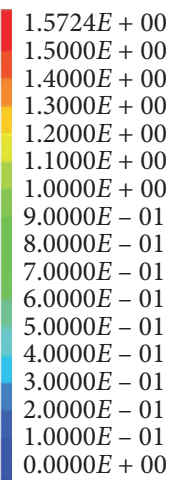

$0.0000 E+00$

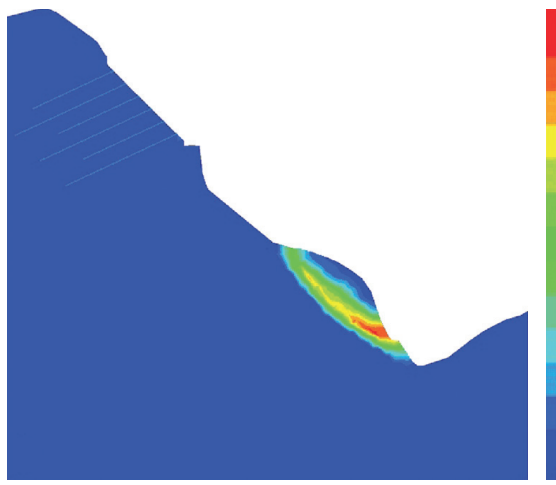

$3.6828 E-01$

$3.6000 E-01$

$3.3000 E-01$

$3.0000 E-01$

$2.7000 E-01$

$2.4000 E-01$

$2.1000 E-01$

$1.8000 E-01$

$1.5000 E-01$

$1.2000 E-01$

$9.0000 E-02$

$6.0000 E-02$

$3.0000 E-02$

$0.0000 E+00$

(b)

Figure 14: Numerical simulation results for the residual soil under rainfall conditions after the mitigation with anchor cables $\left(2-2^{\prime}\right.$ cross section). (a) Contour of the outward displacement. (b) Contour of the shear strain increment. 
discussed the phenomenon as "fire hose effect." Therefore, the stability of the deposits under the flood should be carefully evaluated, keeping in mind the superimposed effects of saturation and erosion.

(3) An assumption is made that the lateral erosion by flooding or runoff significantly affects the stability of the bank slopes. Henceforward, calculation models considering erosion rates at different flow velocities and water levels, as well as corresponding modelling experiments, should be considered as a topic of further studies.

\section{Conclusion}

The G1002 electricity pylon landslide at the Jinping I Hydropower Station was a small tractive shallow landslide, which threatened the safety of the whole transmission network system. The steep interface between the deposit and the bedrock, large-volume excavation of the dam abutment slope, vibrations from multiple blasting activities, and the once-in-a-century rainfall on August 29 to 30, 2012, were key causes of the landslide. Significantly, the superimposed effects of the soil saturation induced by long-term preceding precipitation and lateral erosion of the flood could be crucial triggers of the landslide occurrence.

A sharp gully bend, where the bed gradient vertically decreases from $36^{\circ}$ to $16^{\circ}$ and the strike horizontally deflects from $291^{\circ}$ to $275^{\circ}$, could produce local turbulent flow. Therefore, similar topographical effects can intensify the lateral erosion from the short-term flood and destabilize the electricity pylon slope. In order to avoid similar landslides, when selecting construction sites of electricity pylons in alpine valleys, advanced reinforcement of unfavorable structural planes and concave banks should be implemented.

Considering the traffic conditions, construction cost, implementation, and engineering disturbances, the anchor cables with lattice frame beams and crack sealing were proposed as mitigation measures to protect the foundation of the G1002 electricity pylon. These measures are worth popularizing to prevent shallow colluvium landslides, especially for those with steep sliding planes.

\section{Data Availability}

All data, models, and codes generated or used during the study are included within the manuscript, which can also be made available from the corresponding author upon reasonable request.

\section{Conflicts of Interest}

The authors declare no conflicts of interest.

\section{Acknowledgments}

This study was supported by the National Key Research and Development Program of China (2018YFC1505404) and the National Natural Science Foundation of China (41672283, 41731285 , and 41502299). The authors would like to thank
Editage (http://www.editage.cn) for English language editing.

\section{References}

[1] G. Luo, X. Hu, E. T. Bowman, and J. Liang, "Stability evaluation and prediction of the Dongla reactivated ancient landslide as well as emergency mitigation for the Dongla bridge," Landslides, vol. 14, no. 4, pp. 1403-1418, 2017.

[2] G. Ma, X. Hu, Y. Yin, G. Luo, and Y. Pan, "Failure mechanisms and development of catastrophic rockslides triggered by precipitation and open-pit mining in Emei, Sichuan, China," Landslides, vol. 15, no. 7, pp. 1401-1414, 2018.

[3] J. A. Coe, P. A. Glancy, and J. W. Whitney, "Volumetric analysis and hydrologic characterization of a modern debris flow near Yucca Mountain, Nevada," Geomorphology, vol. 20, no. 1-2, pp. 11-28, 1997.

[4] P. G. Griffiths, R. H. Webb, and T. S. Melis, "Frequency and initiation of debris flows in Grand Canyon, Arizona," Journal of Geophysical Research Earth Surface, vol. 109, no. 4, pp. 1815-1830, 2004.

[5] S. A. Anderson and N. Sitar, "Analysis of rainfall-induced debris flows," Journal of Geotechnical Engineering, vol. 121, no. 7, pp. 544-552, 1995.

[6] M. Berti and A. Simoni, "Experimental evidences and numerical modelling of debris flow initiated by channel runoff," Landslides, vol. 2, no. 3, pp. 171-182, 2005.

[7] I. Hamdhan and H. Schweiger, "Finite element method-based analysis of an unsaturated soil slope subjected to rainfall infiltration," International Journal of Geomechanics, vol. 13, no. 5, pp. 653-658, 2012.

[8] Y. TangZhou, Y. Cheng, J. Liang, and W. Wang, "Heavyrainfall-induced catastrophic rockslide-debris flow at Sanxicun, Dujiangyan, after the Wenchuan ms 8.0 earthquake," Landslides, vol. 13, no. 1, pp. 9-23, 2016.

[9] K. He, G. Ma, X. Hu et al., "Characteristics and mechanisms of coupled road and rainfall-induced landslide in Sichuan China," Geomatics, Natural Hazards and Risk, vol. 10, no. 1, pp. 2313-2329, 2019.

[10] A. J. Negri, N. Burkardt, J. H. Golden et al., "The hurricaneflood-landslide continuum," Bulletin of the American Meteorological Society, vol. 86, no. 9, pp. 1241-1247, 2005.

[11] J.-Q. Zhuang, P. Cui, Y.-G. Ge, Y.-P. He, Y.-H. Liu, and X.-J. Guo, "Probability assessment of river blocking by debris flow associated with the Wenchuan Earthquake," International Journal of Remote Sensing, vol. 31, no. 13, pp. 34653478, 2010.

[12] H. Fang, P. Cui, L. Z. Pei, and X. J. Zhou, "Model testing on rainfall-induced landslide of loose soil in Wenchuan earthquake region," Natural Hazards and Earth System Sciences, vol. 12, no. 3, pp. 527-533, 2012.

[13] P. Cui, X. J. Guo, and J. Q. Zhuang, "Determination of the runoff threshold for triggering debris flows in the area affected by the Wenchuan earthquake," Natural Hazards and Earth System Sciences Discussions, vol. 2, no. 7, pp. 4659-4684, 2014.

[14] C.-X. Guo, J.-W. Zhou, P. Cui, M.-H. Hao, and F.-G. Xu, "A theoretical model for the initiation of debris flow in unconsolidated soil under hydrodynamic conditions," Natural Hazards and Earth System Sciences Discussions, vol. 2, no. 6, pp. 4487-4524, 2014.

[15] S. Lacasse and F. Nadim, "Landslide risk assessment and mitigation strategy," in Landslides-isaster Risk Reduction, K. Sassa and P. Canuti, Eds., Springer, Berlin, Germany, 2009. 
[16] A. Messeri, M. Morabito, G Messeri et al., "Weather-related flood and landslide damage: a risk index for Italian regions," PLoS One, vol. 10, no. 12, Article ID e0144468, 2015.

[17] T. Takahashi, "Mechanical characteristics of debris flow," ASCE Journal of the Hydraulics Division, vol. 104, no. 8, pp. 1153-1169, 1978.

[18] Y. Zhao, Y. Wang, and W. Nie, "Geological hazards prediction and prevention for transmission tower foundation on steep slopes," Soil Engineering and Foundation, vol. 28, no. 6, pp. 108-119, 2014, in Chinese.

[19] R. Huang, F. Lin, and M. Yan, "Deformation mechanism and stability evaluation for the left abutment slope of Jinping I hydropower station," Bulletin of Engineering Geology and the Environment, vol. 69, no. 3, pp. 365-372, 2010.

[20] S. Qi, F. Wu, Y. Zhou, Y. Song, and M. Gong, "Influence of deep seated discontinuities on the left slope of Jinping I hydropower station and its stability analysis," Bulletin of Engineering Geology and the Environment, vol. 69, no. 3, pp. 333-342, 2010.

[21] M. Gong, S. Qi, and J. Liu, "Engineering geological problems related to high geo-stresses at the Jinping I Hydropower Station, Southwest China," Bulletin of Engineering Geology and the Environment, vol. 69, no. 3, pp. 373-380, 2010.

[22] S. W. Song, B. Y. Xiang, J. X. Yang, and X. M. Feng, "Stability analysis and reinforcement design of high and steep slopes with complex geology in abutment of Jinping I hydropower station," Chinese Journal of Rock Mechanics and Engineering, vol. 29, no. 3, pp. 442-458, 2010, in Chinese.

[23] S. Qi, F. Wu, F. Yan, and H. Lan, "Mechanism of deep cracks in the left bank slope of Jinping first stage hydropower station," Engineering Geology, vol. 73, no. 1-2, pp. 129-144, 2004.

[24] S. Song, D. Cai, X. Feng, X. Chen, and D. Wang, "Safety monitoring and stability analysis of left abutment slope of Jinping I hydropower station," Journal of Rock Mechanics and Geotechnical Engineering, vol. 3, no. 2, pp. 117-130, 2011.

[25] National Seismic Standardization Technical Committee, Seismic Ground Motion Parameters Zonation Map of China (GB18306-2015), China Standard Press, Beijing, China, 2015.

[26] F. Wu, X. Hu, M. Gong, J. Liu, and A. Ren, "Unloading deformation during layered excavation for the underground powerhouse of Jinping I Hydropower Station, Southwest China," Bulletin of Engineering Geology and the Environment, vol. 69, no. 3, pp. 343-351, 2010.

[27] Y. Li, W. Zhu, J. Fu, Y. Guo, and Y. Qi, “A damage rheology model applied to analysis of splitting failure in underground caverns of Jinping I hydropower station," International Journal of Rock Mechanics and Mining Sciences, vol. 71, pp. 224-234, 2014.

[28] N. W. Xu, F. Dai, Z. Z. Liang, Z. Zhou, C. Sha, and C. A. Tang, "The dynamic evaluation of rock slope stability considering the effects of microseismic damage," Rock Mechanics and Rock Engineering, vol. 47, no. 2, pp. 621-642, 2013.

[29] C. Zhu, M. He, M. Karakus, X. Cui, and Z. Tao, "Investigating toppling failure mechanism of anti-dip layered slope due to excavation by physical modelling," Rock Mechanics and Rock Engineering, 2020.

[30] Y. Ben-Zion and V. Lyakhovsky, "Analysis of aftershocks in a lithospheric model with seismogenic zone governed by damage rheology," Geophysical Journal International, vol. 165, no. 1, pp. 197-210, 2006.

[31] H. Ochiai, Y. Okada, G. Furuya et al., "A fluidized landslide on a natural slope by artificial rainfall," Landslides, vol. 1, no. 3, pp. 211-219, 2004.
[32] F. Ali, K. Farooq, H. Mujtaba, A. Riaz, and E. Ulhaq, "Influence of saturation on rainfall generated landslides in shale along Murree-Kohala road, Pakistan," Journal of the Geological Society of India, vol. 88, no. 6, pp. 718-724, 2016.

[33] J. Wartman, D. R. Montgomery, S. A. Anderson et al., "The 22 march 2014 Oso landslide, Washington, USA," Geomorphology, vol. 253, pp. 275-288, 2016.

[34] V. Senthilkumar, S. S. Chandrasekaran, and V. B. Maji, "Rainfall-induced landslides: case study of the Marappalam landslide, Nilgiris district, Tamil Nadu, India," International Journal of Geomechanics, vol. 18, no. 9, Article ID 05018006, 2018.

[35] G. F. Wieczorek, "Effect of rainfall intensity and duration on debris flows in central Santa Cruz Mountains, California," Debris Flows/Avalanches: Process, Recognition, and Mitigation, vol. 7, pp. 93-104, 1987.

[36] S. H. Cannon and S. D. Ellen, "Rainfall that resulted in abundant debris-flow activity during the storm," in Landslides, Floods, and Marine Effects of the Storm of January 3-5, 1982, in the San Francisco Bay Region, California, pp. 27-33, U. S. Government Printing Office, Washington, DC, USA, 1988.

[37] F. Cappa, Y. Guglielmi, V. M. Soukatchoff, J. Mudry, C. Bertrand, and A. Charmoille, "Hydromechanical modeling of a large moving rock slope inferred from slope levelling coupled to spring long-term hydrochemical monitoring: example of the La Clapière landslide (Southern Alps, France)," Journal of Hydrology, vol. 291, no. 1-2, pp. 67-90, 2004.

[38] F. Cai and K. Ugai, "Numerical analysis of rainfall effects on slope stability," International Journal of Geomechanics, vol. 4, no. 2, pp. 69-78, 2004.

[39] A. Rahimi, H. Rahardjo, and E.-C. Leong, "Effect of antecedent rainfall patterns on rainfall-induced slope failure," Journal of Geotechnical and Geoenvironmental Engineering, vol. 137, no. 5, pp. 483-491, 2011.

[40] C.-H. Lin and M.-L. Lin, "Evolution of the large landslide induced by Typhoon Morakot: a case study in the Butangbunasi river, southern Taiwan using the discrete element method," Engineering Geology, vol. 197, pp. 172-187, 2015.

[41] C.-S. Tang, D.-Y. Wang, B. Shi, and J. Li, "Effect of wettingdrying cycles on profile mechanical behavior of soils with different initial conditions," Catena, vol. 139, pp. 105-116, 2016.

[42] K. Müller, S. Katuwal, I. Young et al., "Characterising and linking X-ray CT derived macroporosity parameters to infiltration in soils with contrasting structures," Geoderma, vol. 313, pp. 82-91, 2018.

[43] S. Chen, D. Yin, N. Jiang, F. Wang, and Z. Zhao, "Mechanical properties of oil shale-coal composite samples," International Journal of Rock Mechanics and Mining Sciences, vol. 123, Article ID 104120, 2019.

[44] D. Liu, Z. Gu, R. Liang et al., "Impacts of pore-throat system on fractal characterization of tight sandstones," Geofluids, vol. 2020, no. 9, pp. 1-17, 2020.

[45] N. Zhang, W. Liu, Y. Zhang, P. Shan, and X. Shi, "Microscopic pore structure of surrounding rock for underground strategic petroleum reserve (SPR) caverns in bedded rock salt," Energies, vol. 13, no. 7, p. 1565, 2020.

[46] R. M. Iverson, M. E. Reid, N. R Iverson et al., "Acute sensitivity of landslide rates to initial soil porosity," Science, vol. 290, no. 5491, pp. 513-516, 2000.

[47] R. I. Borja, J. A. White, X. Liu, and W. Wu, "Factor of safety in a partially saturated slope inferred from hydro-mechanical continuum modeling," International Journal for Numerical 
and Analytical Methods in Geomechanics, vol. 36, no. 2, pp. 236-248, 2012.

[48] S. Qi and S. K. Vanapalli, "Influence of swelling behavior on the stability of an infinite unsaturated expansive soil slope," Computers and Geotechnics, vol. 76, pp. 154-169, 2016.

[49] J.-W. Zhou, P. Cui, and M.-H. Hao, "Comprehensive analyses of the initiation and entrainment processes of the 2000 Yigong catastrophic landslide in Tibet, China," Landslides, vol. 13, no. 1, pp. 39-54, 2016.

[50] G. Chen, X. Meng, L. Qiao, Y. Zhang, and S. Wang, "Response of a loess landslide to rainfall: observations from a field artificial rainfall experiment in Bailong river basin, China," Landslides, vol. 15, no. 5, pp. 895-911, 2018.

[51] D. N. Petley, "The evolution of slope failures: mechanisms of rupture propagation," Natural Hazards and Earth System Sciences, vol. 4, no. 1, pp. 147-152, 2004.

[52] B. D. Collins and D. Znidarcic, "Stability analyses of rainfall induced landslides," Journal of Geotechnical and Geoenvironmental Engineering, vol. 130, no. 4, pp. 362-372, 2004.

[53] H. Rahardjo, E. C. Leong, and R. B. Rezaur, "Effect of antecedent rainfall on pore-water pressure distribution characteristics in residual soil slopes under tropical rainfall," Hydrological Processes, vol. 22, no. 4, pp. 506-523, 2008.

[54] M. Mukhlisin and M. R. Taha, "Numerical model of antecedent rainfall effect on slope stability at a hillslope of weathered granitic soil formation," Journal of the Geological Society of India, vol. 79, no. 5, pp. 525-531, 2012.

[55] S. K. Vanapalli, D. G. Fredlund, D. E. Pufahl, and A. W. Clifton, "Model for the prediction of shear strength with respect to soil suction," Canadian Geotechnical Journal, vol. 33, no. 3, pp. 379-392, 1996.

[56] N. Lu and W. J. Likos, "Suction stress characteristic curve for unsaturated soil," Journal of Geotechnical and Geoenvironmental Engineering, vol. 132, no. 2, pp. 131-142, 2006.

[57] S. Hu, Y. Tan, H. Zhou et al., "Anisotropic modeling of layered rocks incorporating planes of weakness and volumetric stress," Energy Science \& Engineering, vol. 8, no. 3, pp. 789-803, 2020.

[58] X. Hu, H. Tang, and C. Li, "Stability of Huangtupo riverside slumping mass II\# under water level fluctuation of three gorges reservoir," Journal of Earth Science, vol. 23, no. 2, pp. 326-334, 2012.

[59] M. Xia, G. M. Ren, S. S. Zhu, and X. L. Ma, "Relationship between landslide stability and reservoir water level variation," Bulletin of Engineering Geology and the Environment, vol. 74, no. 3, pp. 909-917, 2015.

[60] D. Wang and K. Li, "Study on Qianjiangping landslide due to reservoir water level rise," Disaster and Control Engineering, vol. 2, pp. 15-19, 2007, in Chinese.

[61] C. Wu and Y. Xia, "Seepage response and stability variation during a rainfall in soil landslide," Electronic Journal of Geotechnical Engineering, vol. 19, pp. 17885-17893, 2014.

[62] C. X. Wang, B. T. Shen, J. T Chen et al., "Compression characteristics of filling gangue and simulation of mining with gangue backfilling: an experimental investigation," Geomechanics and Engineering, vol. 20, no. 6, pp. 485-495, 2020.

[63] S. G. Catane, H. B. Cabria, M. A. H. Zarco, R. M. Saturay, and A. A. Mirasol-Robert, "The 17 february 2006 Guinsaugon rock slide-debris avalanche, Southern Leyte, Philippines: deposit characteristics and failure mechanism," Bulletin of Engineering Geology \& the Environment, vol. 67, no. 3, pp. 305320, 2008.
[64] Y. Bao, X. He, A. Wen et al., "Dynamic changes of soil erosion in a typical disturbance zone of China's three gorges reservoir," Catena, vol. 169, pp. 128-139, 2018.

[65] A. Chueasamat, T. Hori, H. Saito, T. Sato, and Y. Kohgo, "Experimental tests of slope failure due to rainfalls using $1 \mathrm{~g}$ physical slope models," Soils and Foundations, vol. 58, no. 2, pp. 290-305, 2018.

[66] L. Z. Wu, Y. Zhou, P. Sun, J. S. Shi, G. G. Liu, and L. Y. Bai, "Laboratory characterization of rainfall-induced loess slope failure," Catena, vol. 150, pp. 1-8, 2017.

[67] N. Jiang, C. Wang, H. Pan, D. Yin, and J. Ma, "Modeling study on the influence of the strip filling mining sequence on mining-induced failure," Energy Science \& Engineering, vol. 8, no. 6, pp. 2239-2255, 2020.

[68] P. Shan and X. Lai, "An associated evaluation methodology of initial stress level of coal-rock masses in steeply inclined coal seams, Urumchi coal field, China," Engineering Computations, vol. 37, no. 6, pp. 2177-2192, 2020.

[69] Z. Fang and J. P. Harrison, "A mechanical degradation index for rock," International Journal of Rock Mechanics and Mining Sciences, vol. 38, no. 8, pp. 1193-1199, 2001.

[70] China Geological Survey, "Specification of Design and Construction for Landslide Stabilization" (GBT32864-2016), China Standard Press, Beijing, China, 2015.

[71] D. Mendjel and S. Messast, "Development of limit equilibrium method as optimization in slope stability analysis," Structural Engineering and Mechanics, vol. 41, no. 3, pp. 339-348, 2012.

[72] C. Zhu, Z. G. Tao, S. Zhao, and S. Yang, "V shaped gully method for controlling rockfall of high-steep slope in China," Bulletin of Engineering Geology and the Environment, vol. 78, no. 1, pp. 2731-2747, 2019.

[73] E. N. Bromhead, The Stability of Slopes, Blackie Academic and Professional, Great Britain, Europe, 1992.

[74] A. M. Johnson and J. R. Rodine, "Debris flow," in Slope Instability, D. Brunsden and D. B. Prior, Eds., pp. 257-361, Wiley, Chichester, England, 1984. 